\title{
The relational impact of social rights judgments: a trust-based analysis
}

\author{
David Vitale ${ }^{\star \dagger}$ (D) \\ Warwick Law School, University of Warwick, UK \\ *Author e-mail: david.vitale@warwick.ac.uk
}

(Accepted 12 November 2021)

\begin{abstract}
There is a growing body of scholarship examining the impact of courts' social rights judgments, especially their distributive impact (ie the extent to which they deliver social rights-related goods and services to the poor and marginalised). Commentators have used this impact to evaluate the effectiveness of courts in realising citizens' social rights. This paper contributes to the scholarship by adding a new 'relational' dimension to our understanding of such impact. It uses the literature on the concept of trust from philosophy, sociology and other disciplines to analyse the impact that social rights judgments have on the relationship between citizens and the political branches of government, and argues that social rights judgments can modify two elements of this relationship that determine the dynamics at play in it: citizens' vulnerability to the political branches with respect to the relevant goods and services; and citizens' uncertainty about the political branches' exercise of control over the goods and services (which can promote the political branches' trustworthiness). By broadening our understanding of these judgments' impact, the paper offers a valuable lens through which to analyse social rights judgments and adds needed nuance to current debates about courts' effectiveness in realising citizens' social rights.
\end{abstract}

Keywords: public law; human rights; social rights; trust; constitutional law

\section{Introduction}

With the global rise of constitutionalised and justiciable social rights (rights to housing, education, health and social security), ${ }^{1}$ researchers are increasingly examining the impact of courts' judgments enforcing these rights. This growing body of work focuses largely on the judgments' distributive impact (ie the extent to which they deliver social rights-related goods and services to the poor and marginalised). ${ }^{2}$ And commentators have used this distributive impact to evaluate the effectiveness

\footnotetext{
${ }^{\dagger} \mathrm{I}$ am grateful to the three anonymous reviewers, as well as Raphaël Girard, Martin Loughlin, Virginia Mantouvalou, Vanessa Munro, Jo Murkens, Aoife Nolan, Colm O’Cinneide, Thomas Poole and Ioanna Tourkochoriti for their helpful comments on previous drafts. I am also grateful to the participants of the Warwick Law School Conference, the European Junior Faculty Forum at the LSE Department of Law, the Constitutional Works-in-Progress Workshop at the UCD Sutherland School of Law and the ESRAN-UKI Summer Workshop for thought-provoking discussions. Any errors are mine.

${ }^{1} \mathrm{C}$ Jung et al 'Economic and social rights in national constitutions' (2014) 62 American Journal of Comparative Law 1043; E Rosevear et al 'Justiciable and aspirational economic and social rights in national constitutions' in KG Young (ed) The Future of Economic and Social Rights (Cambridge: Cambridge University Press, 2019) p 37.

${ }^{2}$ See DM Brinks and V Gauri 'The law's majestic equality? The distributive impact of judializing social and economic rights' (2014) 12 Perspectives on Politics 375; J Dugard 'Courts and structural poverty in South Africa: to what extent has the constitutional court expanded access and remedies to the poor?' in DB Maldonado (ed) Constitutionalism of the Global South: The Activist Tribunals of India, South Africa, and Colombia (Cambridge: Cambridge University Press, 2013) p 293; OLM Ferraz 'The right to health in the courts of Brazil: worsening health inequities?' (2009) 11 Health and Human Rights 33; OLM Ferraz 'Harming the poor through social rights litigation: lessons from Brazil' (2011) 89 Texas

(C) The Author(s), 2022. Published by Cambridge University Press on behalf of The Society of Legal Scholars. This is an Open Access article, distributed under the terms of the Creative Commons Attribution licence (https://creativecommons.org/licenses/by/4.0/), which permits unrestricted re-use, distribution, and reproduction in any medium, provided the original work is properly cited.
} 
of courts in realising citizens' social rights. For example, Latin American courts' judgments enforcing the right to health, which have disproportionately benefited in material terms the relatively wealthy and non-marginalised, have been criticised for their 'regressive effects', ${ }^{3}$ and are regarded as a 'betrayal or capture' of the right to health. ${ }^{4}$ Or the fact that Irene Grootboom, the claimant in the famous South African right-to-housing case, died without ever receiving the public housing for which she fought, has been used as a basis for critiquing the Constitutional Court and its approach to enforcing social rights. $^{5}$

However, courts' social rights judgments have impact beyond distributive effects of this sort. As César Rodriguez-Garavito stresses, 'to capture the full range of effects of court decisions, impact studies need to enlarge the conventional theoretical and methodological fields of vision', paying attention to not only the 'direct material effects of court orders' but additionally 'the broader impact'. ${ }^{6}$ This paper adds a new dimension to our understanding of impact by analysing what I will call the 'relational' impact of social rights judgments. By this I mean that in addition to their distributive impact, social rights judgments have consequences which help redefine the relationships that are engaged by social rights. They can modify certain elements that determine the dynamics at play in those relationships, thereby altering those dynamics. These consequences follow, as I will show, from how courts interpret social rights provisions and the remedies that they order in response to violations of the rights.

For instance, in the Grootboom case, the South African Constitutional Court set out for the first time its 'reasonableness review' approach to enforcing its constitution's social rights. The court held that the right to housing in section 26 obliged the state 'to devise and implement a coherent, co-ordinated programme' for public housing and that the court, in enforcing the right, would subject the relevant programmes to a standard of reasonableness. ${ }^{7}$ And as I will explain later, though Irene Grootboom never received public housing in her lifetime, this approach to social rights enforcement - by modifying elements of the relationship between the South African government and its citizens altered the dynamics at play in that relationship.

In this paper, I analyse the impact that social rights judgments have on a particular relationship that between citizens and the political branches of government (which I will call the 'citizengovernment relationship'). ${ }^{8}$ I have chosen this relationship for two reasons. First, my primary objective in this paper is to contribute to the literature on the enforcement of social rights by courts. Since the

Law Review 1643; OLM Ferraz Health as a Human Right: The Politics and Judicialisation of Health in Brazil (Cambridge: Cambridge University Press, 2021); FF Hoffmann and FRNM Bentes 'Accountability for social and economic rights in Brazil' in V Gauri and DM Brinks (eds) Courting Social Justice: Judicial Enforcement of Social and Economic Rights in the Developing World (Cambridge: Cambridge University Press, 2008) p 100; D Landau 'The reality of social rights enforcement' (2012) 53 Harvard International Law Journal 189; S Shankar 'The embedded negotiators: India's higher judiciary and socioeconomic rights' in Maldonado, ibid, p 95. For some exceptions, see M Pieterse 'Health, social movements, and rights-based litigation in South Africa' (2008) 35 Journal of Law and Society 364; C Rodriguez-Garavito 'Beyond the courtroom: the impact of judicial activism on socioeconomic rights in Latin America' (2011) 89 Texas Law Review 1669.

${ }^{3}$ See OLM Ferraz 'Social rights, judicial remedies and the poor' (2019) 18(3) Washington University Global Studies Law Review 569; Ferraz (2021), ibid.

${ }^{4}$ See D Landau and R Dixon 'Constitutional non-transformation? Socioeconomic rights beyond the poor?' in Young, above n $1, \mathrm{p} 110$.

${ }^{5}$ See J Berger 'Litigating for social justice in post-apartheid South Africa: a focus on health and education' in Gauri and Brinks, above n 2, pp 81-82; K Pillay 'Implementing Grootboom: supervision needed' (2002) 3 ESR Review 13.

${ }^{6}$ Rodriguez-Garavito, above n 2, at 1675-1676. See also C Rodriguez-Garavito 'Beyond enforcement: assessing and enhancing judicial impact' in M Langford et al Social Rights Judgments and the Politics of Compliance (Cambridge: Cambridge University Press, 2017) p 82.

${ }^{7}$ Government of the Republic of South Africa v Grootboom [2000] ZACC 19, at [95], [41].

${ }^{8} \mathrm{I}$ am assuming a social democracy in which social rights are constitutionalised (and so, owed to citizens); thus, I do not address why the state owes its citizens social rights or the role that trust plays in the state granting such rights. For relevant work on those issues, see LS Underkuffler 'Property, sovereignty, and the public trust' (2017) 18 Theoretical Inquiries in Law 329; LS Underkuffler 'Fiduciary theory: the missing piece for positive rights' in E Criddle (ed) Fiduciary Government (Cambridge: Cambridge University Press, 2018) p 96. Further, I do not mean 'citizens' in the sense of citizenship as legal 
focus of that literature is on how courts mediate the citizen-government relationship, it makes sense to focus my relational impact analysis on that relationship. Secondly, and relatedly, owing to reasons of capacity and democratic legitimacy, it is reasonable to say, as most commentators have, that the political branches have primary responsibility for the realisation of citizens' social rights. ${ }^{9}$ And courts, in enforcing the relevant rights and delivering their social rights judgments, oversee the citizengovernment relationship (alongside, of course, other actors, including administrative tribunals and ombudsmen).

By adding this relational dimension, this paper contributes to current debates about courts' effectiveness in realising citizens' social rights. As Daniel Brinks says, '[w]hether we think courts are "effective" ... depends on our prior expectations'. ${ }^{10}$ If we expect social rights judgments to deliver social rights-related goods and services to the poor and marginalised, then the Latin American and South African experiences detailed above support a thesis, at least in part, of courts' ineffectiveness. I propose, however, in line with scholarship advocating more relational and less individualistic approaches to law, ${ }^{11}$ that broadening our understanding of impact to include relational impact enables us to think more deeply about what social rights judgments can, and should, achieve. As Jennifer Nedelsky has stated:

people will do a better job of making all the difficult decisions involving rights if they focus on the kinds of relationships they actually want to foster, what the values at stake in that fostering are, and how different concepts and institutions will best contribute to that fostering. ${ }^{12}$

I do not mean to suggest in this paper that social rights judgments' distributive impact is not relevant or is less relevant than their relational impact. Rather, this paper, by broadening our understanding of impact, encourages us to rethink our expectations about these judgments, and in turn brings muchneeded nuance to our evaluations of courts' effectiveness in realising the relevant rights. Accordingly, in line with Nedelsky's statement, I encourage readers to reflect on 'the kind of citizen-government relationship that they 'want to foster' and how courts - as an institution that oversees that relationship can 'contribute to that fostering'.

For my relational impact analysis, I draw on the literature on the concept of trust from philosophy, sociology and other disciplines to illustrate two specific forms of relational impact that social rights judgments can have on the citizen-government relationship. Using that literature, I argue that courts' social rights judgments can modify two elements of the citizen-government relationship: citizens' vulnerability to the political branches with respect to social rights-related goods and services, and citizens' uncertainty about the political branches' exercise of control over those goods and services. ${ }^{13}$ More specifically, I illustrate how social rights judgments can: (i) mitigate citizens' vulnerability to the political branches with respect to the relevant goods and services; and (ii) reduce citizens' uncertainty about

status. Rather, I use the term to refer to that group of individuals who are afforded the constitutional protection of social rights. Such individuals may include residents or those of other legal status.

${ }^{9}$ See R Gargarella 'Deliberative democracy, dialogic justice and the promise of social and economic rights' in HA Garcia et al (eds) Social and Economic Rights in Theory and Practice: Critical Inquiries (New York: Routledge, 2015) p 108; C Gearty 'Against judicial enforcement' in C Gearty and V Mantouvalou Debating Social Rights (Oxford: Hart Publishing, 2010) p 1; J King Judging Social Rights (Cambridge: Cambridge University Press, 2012) p 41; V Mantouvalou 'In support of legalisation' in Gearty and Mantouvalou, ibid, p 89; C O'Cinneide 'Legal accountability and social justice' in N Bamforth and P Leyland (eds) Accountability in the Contemporary Constitution (Oxford: Oxford University Press, 2013) p 400.

${ }^{10} \mathrm{DM}$ Brinks 'Solving the problem of (non)compliance in social and economic rights litigation' in Langford et al, above $\mathrm{n}$ 6, p 476,

${ }^{11}$ See J Herring Law and the Relational Self (Cambridge: Cambridge University Press, 2019); R Leckey Contextual Subjects: Family, State, and Relational Theory (Toronto: University of Toronto Press, 2008); J Nedelsky Law's Relations: A Relational Theory of Self, Autonomy, and Law (Cambridge: Cambridge University Press, 2011).

${ }^{12}$ Nedelsky, ibid, pp 237-238.

${ }^{13}$ See CA Heimer 'Solving the problem of trust' in KS Cook (ed) Trust in Society (New York: Russell Sage Foundation, 2001) p 40. 
how the political branches will exercise their control over those goods and services in a way that promotes the political branches' 'trustworthiness' with respect to social rights. It must be noted, however, that these two forms of impact are neither comprehensive nor mutually exclusive: they merely illustrate how courts' social rights judgments can impact the citizen-government relationship.

To be clear, my argument is theoretical, not empirical. Unlike the variables studied in most impact literature to date, the framing and parameters of vulnerability and uncertainty are not self-evident. The concepts are also not easily measured. Any attempt to measure them would face significant challenges. ${ }^{14}$ Hence, I advance in this paper a theoretical argument rooted in the literature on trust about what we can reasonably expect the impact of different social rights judgments to be on the citizen-government relationship. My argument is also not prescriptive. That is, I do not claim that social rights judgments ought to have one relational impact over another. And lastly, my argument assumes compliance from the political branches with the relevant social rights judgments. ${ }^{15}$ Of course, such compliance is not a given, with governments often flouting judicial orders. ${ }^{16}$ This does not, however, diminish the value of this paper's relational impact analysis, especially as it pertains to the literature on the enforcement of social rights. In evaluating an approach to judicially enforce social rights, it is beneficial to consider how that approach plays out under ideal circumstances. It provides an indication of the best that approach can offer in terms of the relevant form of impact - in this case, its relational impact, specifically on the citizen-government relationship. Here, compliance from the political branches represents ideal circumstances. That said, any future normative argument that draws on this relational impact analysis to advocate a specific approach to social rights enforcement must factor in the real-word possibility of non-compliance from the political branches, including how to improve such compliance to realise the relevant consequences.

The paper is organised as follows. In section 1, I lay the foundation for my relational impact argument by describing the nature of the citizen-government relationship. In particular, I detail the power asymmetries in that relationship, with its corresponding vulnerability and uncertainty of citizens. Section 2 of the paper is the core of my argument. Drawing on the literature on trust and using social rights cases globally to illustrate, I explain how social rights judgments can have the two forms of impact that I have identified. The final section provides conclusions.

\section{Vulnerability and uncertainty in the citizen-government relationship}

In any social democracy, there is a relationship between citizens and the political branches with respect to social welfare. Citizens pay taxes to the state, and the state, using the revenue collected from those taxes, provides citizens with a range of goods and services by delivering social welfare programmes. Constitutional social rights afford citizens constitutional protection vis-à-vis such goods and services, and they establish corresponding obligations on the state. ${ }^{17}$ This constitutional arrangement gives rise to what I call the 'citizen-government relationship'.

My focus in this paper is constitutional social rights - that is, those social rights that are protected under a national constitution, either expressly or implicitly (and read into the relevant constitution by

\footnotetext{
${ }^{14}$ For example, it would depend on one's conceptualisation of 'vulnerability' and 'uncertainty'. This is a weakness of the empirical literature on public trust in government: see KS Cook et al Cooperation Without Trust? (New York: Russell Sage Foundation, 2005) p 164. Moreover, it would be difficult, if not impossible, to control for the singular impact of social rights judgments: see DWL Wang 'From Wednesbury unreasonableness to accountability for reasonableness' (2017) 76 Cambridge Law Journal 642 at 658.

${ }^{15}$ On the distinction between 'impact' and 'compliance' see M Langford 'Introduction: from jurisprudence to compliance' in Langford et al, above n 6, p 3; Rodriguez-Garavito, above n 6. That said, the compliance of the political branches can arguably be improved by courts using 'stronger' remedies, including supervisory and contempt orders.

${ }^{16}$ See Brinks, above n 10, p 475; A Chilton and M Versteeg 'Rights without resources: the impact of constitutional social rights on social spending' (2017) 60 Journal of Law and Economics 713 at 720; Pillay, above n 5.

${ }^{17}$ In referring to 'social rights', I am concerned mainly with rights to housing, education, health and social security; and in line with the orthodoxy in the social rights literature, I am not concerned with labour rights.
} 
a court). They are my focus, in significant part, because they have been the focus of the literature on the distributive impact of social rights judgments, with that literature centring on the jurisdictions of South Africa, Brazil and Colombia, in particular. That said, the argument that I advance on the relational impact of social rights judgments is not necessarily limited to constitutional social rights. Courts' enforcement or application of other social rights (eg legislative social rights) can likewise have the relational impact that I describe.

As I indicated earlier, the political branches assume primary responsibility for realising citizens' social rights. The legislature contributes amendments to and promulgates the primary legislation that defines the parameters of state-delivered social welfare programmes. ${ }^{18}$ It also endorses the budget that allows the state to fund and deliver the programmes. The executive, a category in which I include civil servants and the many administrative agencies relevant to social welfare, prepares the bulk of primary legislation introduced to the legislature, and supplements, amplifies and implements that legislation via a range of administrative action. ${ }^{19}$

Citizens are necessarily vulnerable to the political branches with respect to social rights-related goods and services. This vulnerability follows on from three features of the citizen-government relationship. ${ }^{20}$ The first is the fact that citizens need the relevant goods and services. Social rights promise those goods and services that citizens need to lead a decent life. ${ }^{21}$ Therefore, I will proceed under the assumption that the relevant goods and services are needed by citizens. Secondly, citizens' vulnerability to the political branches follows on from the control that the political branches exercise over the goods and services. ${ }^{22}$ This control is exercised via the various legislative and administrative steps described above. ${ }^{23}$ These legislative and administrative steps are prerequisites to the relevant social welfare programmes. And lastly, citizens are vulnerable to the political branches owing to the latter's discretion in exercising that control. As Kenneth Culp Davis explains, a 'public officer has discretion whenever the effective limits on his power leave him free to make a choice among possible courses of action or inaction'. ${ }^{24}$ Leaving aside for the moment any constraints imposed by the courts in enforcing social rights (which I do consider later), both political branches undoubtedly exercise discretion. The legislature can choose to approve (or not approve) the executive's proposed budget, and it can choose to promulgate (or not or propose amendments to) legislation put before it. ${ }^{25}$ Administrative decision-makers also exercise significant discretion, including discretion that is expressly afforded to them under statute, interpretive discretion that arises from vague or ambiguous statutory language, and the various 'administrative choices' that comprise the administrative decision-making process. ${ }^{26}$ And while it is true that this discretion can be restrained by express constitutional language, given

\footnotetext{
${ }^{18}$ King, above n 9, pp 41, 44.

${ }^{19}$ Ibid, pp 44-48; L Sossin 'Boldly going where no law has gone before: call centres, intake scripts, database fields, and discretionary justice in social assistance’ (2004) 42 Osgoode Hall Law Journal 363 at 364-365.

${ }^{20}$ For more on these three features, see D Vitale 'A trust network model for social rights fulfilment' (2018) 38 Oxford Journal of Legal Studies 706.

${ }^{21} \mathrm{C}$ Fabre Social Rights under the Constitution: Government and the Decent Life (Oxford: Oxford University Press, 2003) p 7; King, above n 9, p 17.

${ }^{22}$ See O’Cinneide, above n 9, p 400.

${ }^{23}$ King, above n 9; P Macklem 'Social rights in Canada' in D Barak-Erez and AM Gross (eds) Exploring Social Rights: Between Theory and Practice (London: Bloomsbury, 2007); M Tushnet Weak Courts, Strong Rights: Judicial Review and Social Welfare Rights in Comparative Constitutional Law (Princeton, Princeton University Press, 2008); K Young Constituting Economic and Social Rights (Oxford: Oxford University Press, 2012).

${ }^{24}$ KC Davis Discretionary Justice: A Preliminary Inquiry (Baton Rouge: Louisiana State University Press, 1969) p 4. For similar definitions of discretion, see DJ Galligan Discretionary Power: A Legal Study of Official Discretion (Oxford: Clarendon Press, 1986) p 21; RE Goodin Reasons for Welfare: The Political Theory of the Welfare State (Princeton: Princeton University Press, 1988) p 18; J Jowell 'The legal control of administrative discretion' (1973) 18 PL 178 at 179.

${ }^{25}$ King, above n 9, pp 250-286.

${ }^{26} \mathrm{RE}$ Goodin 'Welfare, rights and discretion' (1986) 6 Oxford Journal of Legal Studies 232; RM Titmuss 'Welfare "rights", law and discretion' (1971) 42 The Political Q 113; Sossin, above n 19.
} 
the vagueness with which social rights are often formulated, such restraint is in most circumstances minimal. $^{27}$

These three features generate vulnerability in citizens toward the political branches as the political branches, in exercising their control, may or may not choose to provide the relevant goods and services to citizens. In other words, the political branches hold power over citizens. And as a result, citizens may not be able to obtain the goods and services that they need - at least not from the state. To be fair, vulnerability and power in the citizen-government relationship operate in both directions. The political branches are likewise vulnerable to citizens who, owing to their voting rights (if any), have the power to remove government officials from office. However, this power is limited because it is exercised infrequently (ie whenever elections are held) and some citizens - especially the poor and marginalised - have limited influence over the democratic process. ${ }^{28}$ It is for this reason that the enforcement of social rights by courts, it has long been argued, is so important: it offers poor and marginalised citizens an alternative forum in which their interests may be better protected, and it supplements the political accountability that follows from voting, with legal accountability. ${ }^{29}$

To be clear, what I am characterising as 'vulnerability' has been described more specifically as 'dependence'. ${ }^{30}$ Both Susan Dodds and Margaret Urban Walker, in their work on vulnerability, define 'dependence' as vulnerability to a specific person given a certain relationship. For Dodds, '[d]ependence is vulnerability that requires the support of a specific person (or people)', in contrast to 'those vulnerabilities that do not involve immediate reliance on specific individuals'. ${ }^{31}$ And similarly, for Walker, 'dependence' means that the actor who 'holds control of the vulnerability stands in a particular sort of relation to the one who has the vulnerability'. ${ }^{32}$ While I could use the term 'dependence', I have chosen to use the language of 'vulnerability' to be consistent with the terminology used in the literature on trust.

Relatedly, owing to the political branches' discretion, citizens are also uncertain about the political branches' exercise of control over the relevant goods and services. This uncertainty exists on multiple levels. There is, of course, citizens' uncertainty about the outcome of the political branches' exercise of control. Whenever a political decision is made, there is inevitably uncertainty that a citizen will not receive what she wants from the political process. ${ }^{33}$ In social rights matters, there is a limited budget available to the political branches in funding and delivering the relevant goods and services. Governments cannot fund and deliver every good and service to every citizen; and as a result, some citizens will necessarily be left unhappy or dissatisfied with the political process's outcome. There is also citizens' uncertainty about how the political branches will exercise their control. The relevant political actors may, for instance, not follow fair procedures or not base their decisions on the best available evidence. ${ }^{34}$

\footnotetext{
${ }^{27}$ King, above n 9, pp 100-106.

${ }^{28}$ S Fredman Human Rights Transformed: Positive Rights and Positive Duties (Oxford: Oxford University Press, 2008) p 34; King, above n 9, pp 157-169; P O’Connell Vindicating Socio-Economic Rights: International Standards and Comparative Experiences (New York: Routledge, 2013) p 5; K Lane Scheppele 'A realpolitik defense of social rights' (2004) 82 Texas Law Review 1921 at 1926-1927.

${ }^{29}$ Gargarella, above n 9, pp 107-108; King, above n 9, p 60; O’Cinneide, above n 9, pp 406-407.

${ }^{30} \mathrm{~S}$ Dodds 'Dependence, care and vulnerability' in C MacKenzie et al (eds) Vulnerability: New Essays in Ethics and Feminist Philosophy (Oxford: Oxford University Press, 2013) p 181; MU Walker Moral Understandings: A Feminist Study in Ethics (Oxford: Oxford University Press, 2008). See also MA Fineman 'The vulnerable subject: anchoring equality in the human condition' (2008) 20 Yale Journal of Law and Feminism 1.

${ }^{31}$ Dodds, ibid, pp 182-83.

${ }^{32}$ Walker, above n 30, p 90.

${ }^{33}$ See Gearty, above n 9, pp 53-54. See also J Mansbridge 'Social and cultural causes of dissatisfaction with US government' in JS Nye Jr et al (eds) Why People Don't Trust Government (Cambridge: Harvard University Press, 1997) p 134; ME Warren 'Democratic theory and trust' in ME Warren (ed) Democracy and Trust (Cambridge: Cambridge University Press, 1999) p 311.

${ }^{34}$ Again, this leaves aside constraints imposed by courts in enforcing social rights: see $\mathrm{K}$ Roach and G Budlender 'Mandatory relief and supervisory jurisdiction: when is it appropriate, just and equitable?' (2005) 122 South African Law
} 


\section{Two illustrations of relational impact}

This vulnerability and uncertainty give rise to two forms of relational impact that social rights judgments can have on the citizen-government relationship. Here, I explain those forms.

\section{(a) Mitigating citizens' vulnerability}

Via their social rights judgments, courts can modify citizens' vulnerability to the political branches with respect to social rights-related goods and services. As I briefly explain later in this section, courts can both mitigate and augment citizens' vulnerability to the political branches. For this illustration, however, I focus on the former - that is, the mitigation of citizens' vulnerability. I do so for two reasons. First, as should become apparent with the following analysis, I think that courts are much more likely to mitigate citizens' vulnerability than augment it. Secondly, recall that one of the central aims of this paper is to encourage readers to reflect on the kind of citizen-government relationship that they want to foster: most readers, I assume, would not want to foster a relationship in which citizens are more vulnerable.

While all citizens are vulnerable to the political branches owing to their shared need for the goods and services (as detailed above), they are not equally so. A citizen's vulnerability to the political branches depends on whether that citizen can obtain the relevant good or service from an alternative source - that is, a source other than the political branches. If, on the one hand, the political branches are a citizen's only source of a social rights-related good or service, the political branches maintain exclusive control over that good or service. And that exclusive control opens the citizen up to extreme vulnerability. The citizen is at the mercy of the political branches with respect to that good or service. Should the political branches refuse to provide the citizen with the good or service, she is denied it - a good or service that she needs. If, on the other hand, the citizen has the option of obtaining the good or service from an alternative source, the citizen's vulnerability to the political branches is less. In this case, if the political branches refuse to provide the good or service to the citizen, while that citizen may suffer some harm in the form of inconvenience, time or cost, she is not denied the good or service. Rather, she has the option of turning to the alternative source for the good or service that she needs.

The most obvious example of such an alternative source is a private provider. In contemporary social democracies, governments rarely maintain exclusive control over the goods and services that citizens need: there is often available to citizens a private market for the goods and services - at least for those citizens who can afford to obtain the goods and services in that private market. ${ }^{35}$ And following on from what I said above, where a citizen can access a good or service through the private market, his vulnerability to the political branches with respect to that good or service is less. Or to put it another way, where citizens have access to that private market, private providers mitigate their vulnerability to the political branches.

I submit that via their social rights judgments, courts can likewise mitigate citizens' vulnerability to the political branches with respect to social rights-related goods and services. In parallel to private providers, courts can serve as an alternative source of those goods and services. Where a court has broad powers of judicial review, including broad remedial powers (which is so in most constitutional democracies), the court maintains control (albeit indirect control) over the goods and services. It can demand that the political branches provide a citizen with a good or service or reimburse the citizen where she has already paid for the good or service from another source. And owing to their control in this regard, courts can offer citizens another source, alternative to the political branches, of social rights-related goods and services.

In order to mitigate citizens' vulnerability to the political branches, it is not enough, however, that a court has control over social rights-related goods and services. The court may not be willing to exert its

Journal 325; King, above n 9, pp 166-167. See also M Levi 'A state of trust' in V Braithwaite and M Levi (eds) Trust \& Governance (New York: Russell Sage Foundation, 1998) p 95; Warren, ibid, pp 311-313.

${ }^{35}$ Vitale, above n 20. 
control over those goods and services. And if that is the case, the court is only theoretically an alternative source. A court must, rather, signal, in its social rights judgments, that it is willing to exert its control, thereby establishing itself as an alternative source of those goods and services for citizens. To so signal, a court must give social rights substantive content, interpreting social rights as substantive material entitlements, and grant claimants 'simple' or individualised relief that provides those claimants with the good or service that they seek. ${ }^{36}$ In doing so, the court indicates to citizens, as prospective claimants in future social rights cases before the court, that if the political branches do not provide them with a good or service that they need, citizens may turn to the court for that good or service.

The South African Constitutional Court, for example, in its social rights judgments to date, has not signalled its willingness to exert its control over social rights-related goods and services. In applying its 'reasonableness review' approach, the court has preferred to interpret its constitution's social rights provisions as guarantees of a more procedural nature, as opposed to substantive material entitlements; and its preferred remedies have been on the 'weaker' side, leaving the political branches with more discretion as to how to satisfy their obligations. ${ }^{37}$ This judicial approach militates against mitigating citizens' vulnerability to the political branches.

Now, contrast the South African court's approach with the individualised enforcement model that dominates right-to-health adjudication in many Latin American countries. ${ }^{38}$ In that model, the court interprets right-to-health provisions as protecting individually enforceable rights and, where it finds a violation, grants the claimant immediate, individualised relief in the form of the medical treatment that is being sought. An extensively studied example is the Brazilian case. The Brazilian Federal Constitution guarantees the right to health in Article 196, declaring health a 'right of all and a duty of the State'. It provides that the right 'shall be guaranteed by means of social and economic policies aimed at reducing the risk of illness and other hazards and at the universal and equal access to actions and services for its promotion, protection and recovery'. In the late 1990s, the Supreme Federal Tribunal interpreted this right as 'an individual entitlement to the satisfaction of one's health needs with the most advanced treatment available, irrespective of costs'. ${ }^{39}$ And following on from that interpretation, courts in Brazil have used the right to order their government to provide individuals with treatments for various health conditions, including diabetes, HIV/AIDS, Parkinson's disease, hepatitis C, Alzheimer's disease and multiple sclerosis. The 'Brazilian model' for right-to-health adjudication is thus characterised 'by a prevalence of individualized claims demanding curative medical treatment (most often drugs) and by an extremely high success rate for the litigant'. ${ }^{40}$

By interpreting the right to health as an individually enforceable right and granting claimants immediate, individualised relief in the form of medical treatments, the Brazilian court has presented itself to citizens as an alternative source of those treatments. It has signalled to holders of the right that if (or more likely, when) their government refuses to provide them with a medical treatment that they need, they can turn to the court to obtain it. The court thus operates as a 'partial replacement' or 'substitute' for the government. ${ }^{41}$ And by offering its citizens this alternative, I suggest, it has mitigated citizens' vulnerability to their government.

\footnotetext{
${ }^{36}$ On the difference between 'simple' and 'complex' remedies, see K Roach, 'Dialogic remedies' (2019) 17 International Journal of Constitutional Law 860. See also D Landau 'Choosing between simple and complex remedies in socio-economic rights cases' (2019) 69 University of Toronto Law Journal 105.

${ }^{37}$ See D Bilchitz Poverty and Fundamental Rights: The Justification of Socio-Economic Rights (Cambridge: Cambridge University Press, 2007); Tushnet, above n 23; F Veriava 'The Limpopo textbook litigation: a case study into the possibilities of a transformative constitutionalism' (2016) 32 South African Journal on Human Rights 321.

${ }^{38}$ See Landau, above n 2, at 199; D Landau 'South African social rights jurisprudence and the global canon: a revisionist view' in R Dixon and T Roux (eds) Constitutional Triumphs, Constitutional Disappointments: A Critical Account of the 1996 South African Constitution's Local and International Influence (Cambridge: Cambridge University Press, 2018) p 410.

${ }^{39}$ Ferraz (2009), above n 2, p 34.

${ }^{40}$ Ibid.

${ }^{41}$ Landau, above n 2, at 232.
} 
It must be clarified, however, that in signalling their willingness to exert their control over social rights-related goods and services and establishing themselves as an alternative source of those goods and services, courts do not mitigate the vulnerability of all citizens. They mitigate the vulnerability of only those citizens who have access (financially and otherwise) to the courts. Just as a private provider's ability to mitigate citizens' vulnerability to the political branches depends on whether citizens can afford the private market, social rights judgments only mitigate citizens' vulnerability to the political branches to the extent that citizens can take advantage of the alternative access that courts offer. For low-income citizens who do not have the meaningful option of litigating their social rights, courts do not mitigate their vulnerability.

This point aligns with the equity criticism that the individualised enforcement model has received to date in the social rights literature. ${ }^{42}$ Writers have criticised the model because its by-product, it has been argued, is to direct resources to higher-income groups, who have the resources to litigate their social rights, rather than the poor or marginalised. ${ }^{43}$ Because litigation, as we know, is both expensive and time-consuming, there is 'a natural tendency to skew litigation toward higher-income groups because they are more likely to have the resources to learn their rights and hire an effective lawyer', and they are in a position to wait for a judicial resolution. ${ }^{44}$ It effectively enables those in higherincome groups to 'queue-jump'. ${ }^{45}$ In fact, the empirical work on the impact of social rights judgments in various jurisdictions supports this conclusion. ${ }^{46}$ Octàvio Ferraz's work on the right to health in Brazil, for instance, has shown that litigation has 'by and large diverted an increasingly larger amount of the already severely limited health budget to health treatments of dubious effectiveness and priority (mostly expensive new medicines) to a minority of people who are capable to litigate. ${ }^{47}$ And because this contradicts an implicit assumption held by scholars and advocates of social rights - that the key beneficiaries of courts' social rights judgments will be the most poor and marginalised - the individualised model is viewed, as I said earlier, as a 'betrayal or capture of these rights' ${ }^{48}$

My analysis here does not take a position on this criticism per se. It rather supplements it with a relational understanding of the individualised enforcement model, rooted in the concept of vulnerability. The relational impact of the model, I have claimed, is to mitigate - albeit unequally - the vulnerability of citizens. And this mitigated vulnerability yields unequal impact on the more tangible measures identified by others, including citizens' health outcomes.

That said, a court does not need to adopt an individualised enforcement model to establish itself as an alternative source of social rights-related goods and services. The court only needs to grant successful claimants immediate, individualised relief which provides them with the good or service that they seek. The court can use, for instance, what Kent Roach calls 'two-track remedial strategies' that 'combine more immediate relief for successful litigants with longer-term processes designed to achieve systemic reform for both the litigants and similar groups. ${ }^{49}$ By granting successful claimants immediate relief - even though that relief is combined with structural or collective relief that extends beyond the claimants - the court signals its willingness to exert its control over social rights-related goods and services; and citizens know that in the future, they can turn to the court to obtain a needed good or service.

\footnotetext{
${ }^{42}$ See Bilchitz, above n 37, p 203; Chilton and Versteeg, above n 16, at 720; Ferraz (2009), above n 2. For an opposing (or at least less critical) view, see Landau and Dixon, above n 4, p 110.

${ }^{43}$ Chilton and Versteeg, above $\mathrm{n} 16$.

${ }^{44}$ Landau and Dixon, above n 4, p 115.

${ }^{45}$ Roach, above n 36.

${ }^{46}$ Hoffmann and Bentes, above n 2; Ferraz (2009), above n 2; Ferraz (2011), above n 2; Ferraz (2021), above n 2; Landau, above $\mathrm{n} 2$.

${ }^{47}$ Ferraz (2021), above n 2, pp 2-3.

${ }^{48}$ Landau and Dixon, above n 4, pp 111, 113.

${ }^{49} \mathrm{~K}$ Roach 'The challenges of crafting remedies for violations of socio-economic rights' in M Langford (ed) Social Rights Jurisprudence: Emerging Trends in International and Comparative Law (Cambridge: Cambridge University Press, 2009 ) p 57. See also Landau, above n 36.
} 
One concrete example of this is the right-to-health jurisprudence of the Colombian Constitutional Court. Like the Brazilian Supreme Federal Tribunal, the Colombian court has often adopted an individualised model in enforcing its right to health. It has done so specifically via the 'tutela' - a device entitling a person to bring action before any judge 'for the immediate protection of his fundamental rights when that person fears they may be violated by the action or omission of any public authority'. ${ }^{50}$ And as in Brazil, claimants have successfully brought forth tutelas in court to demand medical treatments from their government. In addition to providing individualised relief, however, the Colombian court has also issued, as David Landau has documented, structural remedies that require regulatory authorities to take steps to rectify some of 'the major problems in the system that were driving the individual litigation,. ${ }^{51}$ It has therefore used a two-track remedial strategy, granting claimants individualised relief so that they can obtain the medical treatments that they need, while issuing structural remedies that extend beyond those claimants to address some of the more systemic problems. And as the court's structural remedies have been in addition to, not instead of, individualised relief, with the court not abandoning or even discouraging claimants from bringing individual tutelas, ${ }^{52}$ the court has continued to offer itself as an alternative source of medical treatments to its citizens which, I suggest, has in turn mitigated the citizens' vulnerability to their government.

To be clear, as I indicated at the outset of the paper, I am not proposing here that courts should mitigate citizens' vulnerability to the political branches with respect to social rights-related goods and services. Nor am I suggesting that the mitigated vulnerability of citizens to the political branches is necessarily a good thing. The judicial approach described above which mitigates citizens' vulnerability to the political branches is arguably problematic for reasons of institutional legitimacy and capacity, violating the separation of powers and amounting to the judicial usurpation of the political branches' responsibilities. Furthermore, as the critics of the individualised enforcement model have pointed out, it raises serious issues of equity, especially when individualised relief is not combined with systemic remedies. Rather than advocate that courts mitigate citizens' vulnerability to the political branches, I have simply sought to demonstrate how courts, via their social rights judgments, can mitigate citizens' vulnerability.

Lastly, as I noted at the beginning of this section, courts can also augment citizens' vulnerability to the political branches. Specifically, where a court has already established itself as an alternative source of social rights-related goods and services, it can augment citizens' vulnerability by establishing a new precedent signalling that it is no longer willing to exert its control over those goods and services. By doing so, the court eliminates itself as an alternative source of those goods and services for citizens, leaving citizens with one less source of the goods and services. And this augments citizens' vulnerability to the political branches. For the reasons detailed earlier, however, I have not focused here on this form of relational impact.

\section{(b) Reducing citizens' uncertainty and promoting the political branches' trustworthiness}

Another form of relational impact that courts can have via their social rights judgments is to modify citizens' uncertainty about how the political branches will exercise their control over social rights-related goods and services. This includes citizens' uncertainty about whether the relevant political actors will follow fair procedures and whether they will base their decisions on the best available evidence. And based on my reading of the literature on trust, by modifying this uncertainty, courts can impact the political branches' trustworthiness with respect to social rights. As with the previous section, courts can both reduce and augment citizens' uncertainty. For this illustration, however, I again focus on the former - that is, the reduction of citizens' uncertainty which, in turn, promotes the political branches' trustworthiness. And I do so for the same reasons as last time: I think that courts are

\footnotetext{
${ }^{50}$ Constitution of Colombia, cited in Landau, above n 2, at 205 (fn 67).

${ }^{51}$ Landau, above n 36, at 109.

${ }^{52}$ Ibid, at $109-110$.
} 
much more likely to reduce citizens' uncertainty than augment it; and I again assume that most readers would not want to foster a citizen-government relationship in which the political branches are less trustworthy.

To develop my argument that courts can reduce citizens' uncertainty and promote the political branches' trustworthiness, I will start with what the concept of trustworthiness means. Trustworthiness follows on from the concept of trust. As the term itself suggests, trustworthiness implies that an actor is worthy of our trust in them. ${ }^{53}$ It represents the likelihood that that actor will fulfil our trust in them, thereby proving their trust-worthiness. The more likely they are to fulfil our trust in them, the more trustworthy they are. And so, for the political branches to be 'trustworthy' means that they are likely to fulfil citizens' trust in them.

Given this link, before we can understand trustworthiness, we must first understand trust. While trust, it is well-recognised in the literature, operates at multiple levels, including affective and behavioural levels, my focus here will be on trust at the cognitive level. In other words, I am interested in trust at the level of thoughts or beliefs held by the trusting party. At the cognitive level, trust is a set of expectations that we hold about another actor with respect to some trusted subject matter. ${ }^{54}$ And trustworthiness, it therefore follows, is the likelihood of that actor fulfilling those expectations. Specifically, trust is commonly defined in terms of two expectations: goodwill and competence. ${ }^{55}$ In trusting an actor we expect that actor: (i) to exercise goodwill towards us; and (ii) to be competent with respect to the trusted subject matter. Accordingly, if we apply this definition of trust to the citizen-government relationship, for citizens to 'trust' the political branches, specifically with respect to social rights-related goods and services (or more briefly, with respect to social rights), means that citizens expect the political branches to exercise goodwill towards them in exercising their control over social rights-related goods and services, and for them to be competent to exercise that control. And it therefore follows once again that for the political branches to be trustworthy with respect to social rights means that the political branches are likely to fulfil these two expectations. The more likely the political branches are to fulfil the expectations, the more trustworthy they are.

In a political relationship like the citizen-government relationship, the expectation of goodwill translates (at least in significant part) into an expectation of procedural fairness. ${ }^{56}$ Fair procedures signify that a trusted party, like the political branches, "means well," that is, the party appears to want to live up to its commitments'. ${ }^{57}$ This suggests that in trusting the political branches with respect to social rights, citizens expect the political branches to adopt fair procedures when exercising their control over social rights-related goods and services. And accordingly, for the political branches to be trustworthy means, as Margaret Levi explains, that they have 'procedures for making and implementing policy that

\footnotetext{
${ }^{53}$ See A Baier 'What is trust?' in D Archard et al (eds) Reading Onora O’Neill (New York: Routledge, 2013) p 184. For this reason, some writers define trust in a somewhat circular manner in terms of the trusting party's expectations about the trusted party's trustworthiness - that is, a trusting party trusts the trusted party if he expects trustworthiness from her: see L Becker 'Trust as noncognitive security about motives' (1996) 107 Ethics 43 at 44; H Farrell 'Institutions and midlevel explanations of trust' in KS Cook (eds) Whom Can We Trust? How Groups, Networks, and Institutions Make Trust Possible (New York: Russell Sage Foundation, 2009) p 129. See also Mark Warren's idea of 'warranted' trust, and Onora O’Neill's idea of 'intelligent' trust: O O’Neill A Question of Trust (Cambridge: Cambridge University Press, 2002); O O’Neill 'Accountable institutions, trustworthy cultures' (2017) 9 Hague Journal on the Rule of Law 401; Warren, above n 33; ME Warren 'What kinds of trust does a democracy need? Trust from the perspective of democratic theory' in S Zmerli and TWG van der Meer (eds) Handbook on Political Trust (Cheltenham: Edward Elgar, 2017) p 33.

${ }^{54}$ See A Baier 'Trust and antitrust' (1986) 96 Ethics 231; B Barber The Logic and Limits of Trust (New Brunswick: Rutgers University Press, 1983); Becker, ibid; J Brockner and P Siegel 'Understanding the interaction between procedural and distributive justice: the role of trust' in RM Kramer and TR Tyler (eds) Trust in Organizations: Frontiers of Theory and Research (Thousand Oaks: Sage Publications, 1996) p 390; Farrell, ibid.

${ }^{55}$ See Baier, ibid; Barber, ibid; Brockner and Siegel, ibid. See also K Jones 'Trust as an affective attitude' (1996) 107 Ethics 4. For more on this, see D Vitale 'Political trust as the basis for a social rights enforcement framework' (2018) 44 Queen's Law Journal 177.

${ }^{56}$ Brockner and Siegel, above n 54; M Grimes 'Procedural fairness and political trust' in Zmerli and van der Meer, above n 53, p 256; Levi, above n 34 .

${ }^{57}$ Brockner and Siegel, above n 54, p 407.
} 
meet prevailing standards of fairness' ${ }^{58}$ While the specifics of procedural fairness, including what exactly comprises trust's expectation of goodwill, are debatable, the literature on trust recognises that at a minimum, procedural fairness includes transparency and participation (or 'voice'): political actors must publish and provide 'timely and relevant information to [evaluate their] performance' and they must ensure that the 'voice' of those affected is heard in the decision-making process. ${ }^{59}$

The second expectation of trust, competence, maps onto an expectation that the political branches, in exercising their control over social rights-related goods and services, will base their decisions on the best available evidence. ${ }^{60}$ In exercising their control over the relevant goods and services, the political branches make decisions - including which goods and services to fund and deliver, how much to invest in social welfare programmes, and who will be covered by the programmes - in order to serve policy ends. Scientific research, by offering insights into which policy initiatives are the most effective to achieve those ends, is thus of critical value. And the political branches are trustworthy where they base their decisions on such evidence. ${ }^{61}$

Now, relevant to my claim that courts, via their judgments, can promote the political branches' trustworthiness, there is an established line of thinking in the literature on trust that the trustworthiness of a party, like the political branches, can be promoted by constraining the discretion exercised by that party in carrying out whatever functions have been entrusted to them. ${ }^{62}$ For this reason writers on trust distinguish between 'personal' (or primary) trust and 'impersonal' (or secondary) trust. ${ }^{63}$ Whereas personal trust refers to trust that we have in a trusted party based on what we know about their character, impersonal trust refers to trust based on our knowledge of the constraints that have been imposed on them. In both cases of trust, we expect goodwill and competence from the trusted party - but for different reasons. With personal trust, we expect goodwill and competence because we believe that the trusted party is of good character; and that good character, we think, makes them trustworthy. We cannot be sure, but we believe that they are likely to fulfil our expectations of goodwill and competence because they are a good person. With impersonal trust, we expect goodwill and competence from the trusted party because the constraints that have been imposed on them make goodwill and competence likely. The constraints, in other words, make the trusted party trustworthy.

This line of thinking, I propose, can be applied to the citizen-government relationship, and courts in their oversight of that relationship. So applied, it suggests that by imposing constraints on the political branches' discretion vis-à-vis social rights-related goods and services, courts can, via their social rights judgments, promote the trustworthiness of the political branches with respect to social rights. By imposing these constraints, courts reduce citizens' uncertainty about how the political branches will exercise their control over social rights-related goods and services. Put simply, the constraints, imposed by courts in their judgments, offer citizens more certainty about the how that control will be exercised.

Specifically, based on the conceptualisation of trust and trustworthiness detailed above, courts promote the trustworthiness of the political branches where they constrain the political branches' discretion so as to make it more likely that they will fulfil citizens' trust-based expectations of goodwill (that is, that

\footnotetext{
${ }^{58}$ Levi, above n 34, p 88.

${ }^{59}$ Grimes, above n 56, pp 260, 265; TR Tyler 'Social justice: outcome and procedure' (2000) 35 International Journal of Psychology 117; S Ulbig 'Voice is not enough: the importance of influence in political trust and policy assessments' (2008) 72 The Public Opinion Q 523.

${ }^{60}$ Vitale, above n 55.

${ }^{61}$ While it is argued that evidence-based policymaking may not increase public trust, this does not affect its link with trustworthiness: see C Pollitt and N Chambers 'Evidence-based trust: a contradiction in terms?' in S Llewellyn et al (eds) Trust and Confidence in Government and Public Services (New York: Routledge, 2013) p 36.

${ }^{62}$ See R Hardin 'Trustworthiness' (1996) 107 Ethics 26; P Pettit 'Republican theory and political trust' in Braithwaite and Levi, above n 34; SP Shapiro 'The social control of impersonal trust' (1987) 93 American Journal of Sociology 623; L Zucker 'Production of trust: institutional sources of economic structure, 1840 to 1920' (1986) 8 Research in Organizational Behavior 53. See also Piotr Sztompka's discussion of accountability and trust: P Sztompka, Trust: A Sociological Theory (Cambridge: Cambridge University Press, 1999) pp 87-88.

${ }^{63} \mathrm{O}$ Patterson 'Liberty against the democratic state: on the historical and contemporary sources of American trust' in Warren, above n 33, p 154; Pettit, ibid, pp 296, 298-299; Shapiro, ibid; Sztompka, ibid, pp 46-47, 87.
} 
the political branches will adopt fair procedures in making decisions about the relevant goods and services) and competence (that is, that they will base their decisions on the best available evidence). To the extent that a social rights judgment makes the fulfilment of either of these expectations more likely, it promotes the political branches' trustworthiness with respect to social rights. Hence, and more concretely, a social rights judgment promotes such trustworthiness where that judgment creates an obligation on the political branches to: (i) follow fair procedures when making decisions about the relevant goods and services; (ii) base their decisions on the best available evidence; or (iii) both.

A good example of judgments that fit category (i) is the social rights jurisprudence of the South African Constitutional Court, specifically on reasonableness review. While the vague criteria first set out by Yacoob J in Grootboom do very little to require procedural fairness from government actors vis-à-vis social welfare programmes, ${ }^{64}$ since Grootboom, the court has elaborated reasonableness review to make it more concrete and, more importantly for my purpose, to incorporate elements of procedural fairness. And in doing so, I submit, the court's social rights judgments have done work to promote the South African government's trustworthiness. In the well-known TAC decision, for instance, the court incorporated into reasonableness review government transparency. It explained that a reasonable social welfare programme must be transparent such that 'its contents must be made known appropriately' to all concerned. ${ }^{65}$ The court concluded that the public health programme at issue there (which restricted the availability of the antiretroviral drug Nevirapine to limited research and training sites in South Africa) was unreasonable, at least in part, because of the government's lack of transparency. The court stressed that remedying the 'HIV/AIDS challenge facing the country' required 'proper communication, especially by government', and in concluding that there had been a violation of the right to health vis-à-vis the government's Nevirapine programme, the court found that communication of this standard was simply not evident. ${ }^{66}$ And more recently, the court has incorporated an element of participation into reasonableness review via the remedy of 'meaningful engagement'. ${ }^{67}$ In Olivia Road, for example, occupiers of two buildings in the inner city of Johannesburg challenged an order granted by a lower court authorising the City of Johannesburg to evict the occupiers on the basis that those buildings were unsafe and unhealthy. ${ }^{68}$ As part of its resolution of the case, the court issued an order 'aimed at ensuring that the City and the occupiers engaged with each other meaningfully on certain issues', including on the issue of how to make 'the buildings as safe and as conducive to health as is reasonably practicable'. ${ }^{69}$ The court required, in essence, that the building's occupiers be given an opportunity to participate in the City's decision-making process around eviction, as well as the safety and health of the buildings. While meaningful engagement was only a remedy ordered, of note is the fact that the court rooted the requirement to 'meaningfully engage' in the government's overarching obligation to take 'reasonable measures'. Accordingly, the judgment's ultimate effect was, as Anashri Pillay explains, to include as a 'factor for a court to consider in evaluating the reasonableness of government action' the question of meaningful engagement. $^{70}$

The jurisprudence of UK courts regarding the rationing of medical treatment in the National Health Service (NHS) offers another illustration. Now, granted, unlike the other jurisdictions considered in this paper (eg South Africa, Brazil, Colombia), the UK does not have a codified constitution. Accordingly, it does not have constitutional social rights - at least not in the traditional sense. ${ }^{71}$

\footnotetext{
${ }^{64}$ Grootboom, above n 7, [99], [43], [39], [43], [42], [44].

${ }^{65}$ Minister of Health $v$ Treatment Action Campaign [2002] ZACC 15, at [123].

${ }^{66}$ Ibid.

${ }^{67}$ For a summary of the relevant jurisprudence on engagement, see B Ray Engaging with Social Rights: Procedure, Participation, and Democracy in South Africa's Second Wave (Cambridge: Cambridge University Press, 2016).

${ }^{68}$ Occupiers of 51 Olivia Road $v$ City of Johannesburg [2008] ZACC 1.

${ }^{69}$ Ibid, [5].

${ }^{70}$ A Pillay 'Towards effective social and economic rights adjudication: the role of meaningful engagement' (2012) 10 International Journal of Constitutional Law 732 at 745.

${ }^{71}$ The UK does, however, have a constitution which comprises the common law, parliamentary legislation, the royal prerogative and constitutional conventions. And UK courts have used public law to protect social welfare. See SC Matteucci and
} 
However, as I noted earlier, my arguments in this paper are not necessarily limited to constitutional social rights: courts' enforcement or application of legislative social rights can likewise have relational impact. And in the UK, social rights are protected under various statutes, including the National Health Service Acts. ${ }^{72}$ Moreover, while the UK does not have constitutional social rights, as I will explain shortly, UK courts have taken steps to protect social welfare, drawing on their body of public law, which courts in jurisdictions with constitutional social rights could likewise take (or at least parallel). Consequently, in my view, UK cases, despite these differences, offer a good source to illustrate relational impact. As Daniel Wang has documented, UK courts, relying on various grounds of judicial review, have scrutinised NHS rationing decisions both for procedural fairness (illustrating category (i)) and for the evidence used to make those decisions (illustrating category (ii)). ${ }^{73}$ The $A, D$ and $G$ case well-illustrates category (ii). ${ }^{74}$ In that case, the Court of Appeal challenged a local health authority's refusal to fund gender reassignment surgery on the basis that the authority's scientific assessment had not engaged with existing evidence that the surgery was an effective treatment for gender identity dysphoria. Under the National Health Service Act 1977 (in combination with relevant regulations), the local health authority had a duty to provide 'to such extent as [it] considers necessary to meet all reasonable requirements ... such ... services as are required for the diagnosis and treatment of illness'. Until 1995, the authority had funded gender reassignment surgery where a local consultant psychiatrist recommended it as necessary. But in 1995, the authority adopted a policy that allocated a low priority for public funding of procedures that it considered clinically ineffective - and gender reassignment surgery, according to the policy, which was classified as falling in the lowest 10 per cent in terms of priority, would not be funded 'except in cases of overriding clinical need'.

The Court of Appeal quashed the health authority's decision not to fund the surgery, along with the policy on which it was based, and remitted the matter to the authority for reconsideration. Lord Justice Auld reasoned that while it was not the judiciary's place 'to express opinions as to the likelihood of the effectiveness of medical treatment', the health authority's refusal to engage with the evidence, and its follow-on conclusion that there was no effective treatment for gender identity dysphoria, made a 'nonsense' of its policy not to fund low-priority treatments 'except in cases of overriding clinical need'. ${ }^{75}$ The policy, he said, effectively amounted to 'the operation of a "blanket policy" against funding treatment for the condition [gender identity dysphoria] because it [the health authority] does not believe in such treatment'. ${ }^{76}$ In a concurring judgment, Lord Justice Buxton explained that where there is 'a strong and respectable body of medical opinion' that considers a treatment to be effective and suitable (as was the case with gender reassignment surgery), it is 'not open to a rational health authority simply to determine that a procedure has no proven clinical benefit while giving no indication of why it considers that that is so. ${ }^{77}$ And so, Lord Justice Buxton concluded, the health authority's refusal to engage with this evidence rendered its rationing decision irrational.

The above set of social rights judgments, I submit, promote the trustworthiness of the relevant government actors. The South African and UK courts, via their respective judgments, have constrained the relevant actors' discretion vis-à-vis social rights-related goods and services (that is, medical treatments in TAC and A, D and G, and housing in Olivia Road), obliging them to adopt fair procedures in making decisions about the goods and services, to base their decisions on the best available evidence, or both. And in so obliging the actors, these courts have made it more likely that those actors will fulfil citizens' trust-based expectations of goodwill and competence when making decisions about the relevant goods and services.

\footnotetext{
S Halliday 'Social rights, the welfare state and European austerity' in SC Matteucci and S Halliday (eds) Social Rights in Europe in an Age of Austerity (Routledge, 2017) p 9.

${ }^{72}$ King, above n 9, pp 41-42.

${ }^{73}$ Wang, above $\mathrm{n} 14$.

${ }^{74} R v$ North West Lancashire Health Authority, ex $p$ A, D and G [2000] 1 WLR 977.

${ }^{75}$ Ibid, at 993, citing Cambridge Health Authority [1995] 1 WLR 898 at 905.

${ }^{76}$ Ibid, at 994 .

${ }^{77} \mathrm{Ibid}$, at $997-998$.
} 
I should clarify two points. First, the 'constraint' imposed by the court on the political branches can come from either (or both) how the court interprets the social right in question and the remedy that the court orders in response to a decided social rights violation. In the former case, the court interprets a social right as obliging the political branches to follow fair procedures or to base their decisions on the best available evidence. This is what the South African court did, for instance, in TAC vis-à-vis reasonableness and transparency. It interpreted the right to health in section 27 of its constitution as obliging the government to introduce reasonable public health programmes, and it defined a reasonable public health programme as one which is transparent. In the latter case, the court grants the claimants in a particular case a remedy that obliges a government actor to follow fair procedures in that particular situation or to base a specific decision on the best evidence. This is what the court did in Olivia Road vis-à-vis meaningful engagement. It ordered the City of Johannesburg to engage meaningfully with the occupiers of the two buildings on the relevant issues, thereby requiring their participation.

Secondly, because the concept of trustworthiness as conceptualised represents the likelihood of expectations (of goodwill and competence) being fulfilled, and expectations are thoughts or beliefs about events in the future, it follows that for a social rights judgment to promote the political branches' trustworthiness with respect to social rights, the judgment must have what we can describe as 'prospective effect'. By this, I mean that the judgment must constrain the political branches' future conduct so as to make it more likely that the political branches will act with goodwill and/or competence in their future interactions with citizens.

Granted, most social rights judgments will have some prospective effect. A prospective effect may result, for instance, from a judgment's precedential value or from government actors fearing litigation and corresponding judicial repercussions, with them perceiving judges as being over their shoulders' ${ }^{78}$ When the South African Constitutional Court introduced reasonableness review, for example, government actors responded with 'Grootboom-proofing' of social policy. ${ }^{79}$ But the more a court can maximise the prospective effect of its social rights judgment, the more, I submit, it will promote the political branches' trustworthiness.

For example, where the constraint on the political branches' discretion vis-à-vis social rights-related goods and services comes from the remedy ordered by the court in response to a decided social rights violation, the trustworthiness of the political branches can be promoted further, I suggest, by 'institutionalising' that remedy. As Brian Ray explains, to institutionalise a remedy, government actors must adopt measures that 'ensure systematic implementation' of that remedy such that they 'work to develop a more generalised capacity' for the remedy 'outside of specific projects' ${ }^{80}$ The remedy, in other words, must not be a one-off response to the specific situation in the case, but rather integrated into the government's broader decision-making process. By institutionalising a remedy that obliges a government actor in making decisions vis-à-vis social rights-related goods and services to follow fair procedures or to base their decisions on the best available evidence, those ideas - that is, procedural fairness and evidence-based decision-making - become part of the political branches' decision-making process vis-à-vis the relevant goods and services. And it is thus more likely that the political branches will fulfil citizens' trust-based expectations in their future interactions with citizens. So, it follows that the more a court can further a remedy's institutionalisation in its judgment, the more it can promote the political branches' trustworthiness with respect to social rights.

\footnotetext{
${ }^{78}$ See UK Government Legal Department ‘The judge over your shoulder - a guide to good decision making' (2006) https:// assets.publishing.service.gov.uk/government/uploads/system/uploads/attachment_data/file/746170/JOYS-OCT-2018.pdf.

${ }^{79} \mathrm{M}$ Langford and S Kahanovitz 'South Africa: rethinking enforcement narratives' in Langford et al, above n 6, p 331. See also KG Young 'The right-remedy gap in economic and social rights adjudication: holism versus separability' (2019) 69 University of Toronto Law Journal 124 at 133.

${ }^{80}$ B Ray 'Proceduralisation's triumph and engagement's promise in socio-economic rights litigation' (2011) 27 South African Journal on Human Rights 107 at 117. In subsequent work, Ray discusses this in terms of 'institutional reform' drawing on Charles Epp's 'legalized-accountability model': Ray, above n 67, pp 276-278.
} 
This is what the South African Constitutional Court did in Olivia Road. By rooting the remedy of meaningful engagement in the government's overarching duty to take 'reasonable measures', it furthered the institutionalisation of engagement. By doing so, I submit, it further promoted the trustworthiness of the South African government with respect to social rights.

Another concrete example is the UK Supreme Court's decision in Nzolameso, where the court furthered the institutionalisation of greater transparency in local authorities' decision-making about temporary accommodation provision to its homeless residents. ${ }^{81}$ The claimant and her children lived in Westminster in a privately rented house paid for with housing benefits. But with the introduction of a benefit cap, the house became unaffordable for the claimant, rendering her and her children homeless. Under legislation, local authorities like Westminster had a duty to provide accommodation in their own area (that is, 'in borough') 'so far as reasonably practicable'. ${ }^{82}$ Westminster City Council, claiming a shortage of accommodation in Westminster, offered the claimant a house 'out of borough' (approximately one hour and 15 minutes from Westminster). The Supreme Court, on an application for judicial review, held that Westminster had acted unlawfully. And in so holding, Lady Hale, who wrote the court's judgment, issued 'guidance' to local authorities to be applied by them when making temporary accommodation decisions so as to make this public decision-making process more transparent.

Lady Hale specifically stated that 'each local authority should have, and keep up to date, a policy for procuring sufficient units of temporary accommodation to meet the anticipated demand during the coming year. ${ }^{83}$ That policy should reflect the local authority's statutory obligations and should be approved by the democratically accountable members of the council. She also asserted that 'each local authority should have, and keep up to date, a policy for allocating those units to individual homeless households' ${ }^{84}$ Where the council anticipates a shortfall of 'in borough' units, the policy should explain 'the factors which would be taken into account in offering households those units', 'the factors which would be taken into account in offering units close to home' and where a shortage exists, 'the factors which would make it suitable to accommodate a household further away'. ${ }^{85}$ And Lady Hale said both policies 'should be made publicly available', further promoting transparency in the process. ${ }^{86}$

To again be fair, and as I noted at the beginning of this section, courts can also augment citizens' uncertainty about how the political branches will exercise their control over social rights-related goods and services - and in turn, they can make the political branches less trustworthy. This would be the case, I suggest, where a court removed previously-imposed constraints on the political branches (eg under statute or common law) that required them to follow fair procedures or to base their decisions on the best available evidence. By removing these constraints, the court would make goodwill and competence from the political branches less likely and therefore lessen their trustworthiness with respect to social rights. But again, for the reasons detailed earlier, I have not focused here on this form of relational impact.

Lastly, a reader may ask: what about citizens' trust in the courts? Surely the two expectations of trust which I have described here would apply to courts in their enforcement of social rights? This is true. Because trust is best conceptualised as a network of interconnected and interdependent relationships, we could consider the operation of trust in various relationships, including that between citizens and the courts. ${ }^{87}$ However, as my focus in this paper has been the citizen-government relationship (as I identified at the outset), I have not considered trust and trustworthiness in these other relationships. And while those relationships are relevant to trust in the citizen-government relationship, it is beyond the scope of this paper.

\footnotetext{
${ }^{81}$ Nzolameso $v$ City of Westminster [2015] UKSC 22.

${ }^{82}$ Housing Act 1996, s 208(1).

${ }^{83}$ Nzolameso, above $\mathrm{n} 81$, at [39].

${ }^{84}$ Ibid, at [39].

${ }^{85}$ Ibid.

${ }^{86}$ Ibid.

${ }^{87}$ Vitale, above n 20.
} 


\section{Conclusion}

This paper contributes to the growing literature on the impact of social rights judgments, as well as the social rights literature more broadly, by introducing and examining what I have described as the 'relational' impact of these judgments. Courts are very frequently criticised for not doing enough in their social rights judgments to help realise citizens' social rights. At the core of these critiques is often the judgments' distributive impact. It is assumed that to realise citizens' social rights, courts' enforcement of the rights must deliver social rights-related goods and services to the poor and marginalised. If it does not, the courts, and social rights jurisprudence, are treated as ineffective - or at least, as significantly underperforming.

This paper has not sought to challenge these evaluative arguments. The distributive impact of social rights judgments is undoubtedly an important aspect of realising citizens' social rights. As much of the social rights literature assumes, these rights are intended to be transformative in nature, with their greatest beneficiaries being the poor and marginalised. ${ }^{88}$ And the judicial enforcement of social rights, in line with common arguments in support of social rights' justiciability, offers poor and marginalised citizens a forum to better protect their interests (as compared with the democratic process in which they have minimal influence). So, rather than challenge the above evaluative arguments, this paper has instead sought to add some much-needed nuance to them, contributing to the existing literature on 'the broader impact' of social rights judgments. I have argued that in addition to their distributive impact, courts, via their judgments, can have differential impact on the dynamics at play in the citizengovernment relationship - specifically by modifying certain elements of that relationship. And to illustrate this relational impact, I have drawn on the literature on trust to demonstrate two forms of such impact: how courts can mitigate citizens' vulnerability to the political branches with respect to social rights-related goods and services, and how they can reduce citizens' uncertainty to promote the political branches' trustworthiness with respect to social rights.

By broadening our understanding of the impact that social rights judgments have, the paper offers a valuable lens through which to analyse these judgments and evaluate their effectiveness. Though a social rights judgment may not deliver the relevant goods and services to the poor and marginalised, it may have an impact on the relationship between citizens and the political branches. For instance, as I have noted, the South African Constitutional Court's Grootboom judgment did not deliver public housing to Irene Grootboom. It did, however, set out for the first time the court's 'reasonableness review' approach to enforcing social rights which, since Grootboom, has incorporated elements of procedural fairness like transparency and participation. And in doing so, I have argued, the Constitutional Court has promoted the South African government's trustworthiness with respect to social rights. In my view, this relational impact analysis casts the Grootboom judgment, and its effectiveness in realising South Africans' social rights, in a different light. It adds a new dimension to the judgment and perhaps challenges our expectations of what a social rights judgment ought to achieve. With its broader understanding of social rights judgments' impact, this paper thus enables us to think more deeply about the role that courts can, and should, play in social rights enforcement.

\footnotetext{
${ }^{88}$ Landau and Dixon, above n 4, p 113.
}

Cite this article: Vitale D (2022). The relational impact of social rights judgments: a trust-based analysis. Legal Studies 42 , 408-424. https://doi.org/10.1017/lst.2021.57 